\title{
Application of ESI-FAIMS-MS to the Analysis of Tryptic Peptides
}

\author{
David A. Barnett, Barbara Ells, Roger Guevremont, and \\ Randy W. Purves \\ Ionalytics Corporation, Ottawa, Ontario, Canada
}

\begin{abstract}
High-field asymmetric waveform ion mobility spectrometry (FAIMS) separates gas-phase analyte ions from chemical background, offering substantial improvements in the detection of peptides from complex protein digests. For a digest of enolase 1 (baker's yeast), the focusing and separation offered by FAIMS produced an average intensity gain of 3.5 for the tryptic ions and reductions in background intensity of 5- to 10-fold when compared with ESI-MS. The increased signal-to-background in the ESI-FAIMS-MS experiment resulted in a greater number of identifiable peptides and therefore greater sequence coverage. Compensation voltage (CV) maps for a total of 282 tryptic peptides from thirteen proteins, generated according to charge-state, mass-to-charge ratios, and chain length, show that a majority of tryptic peptides can be detected by operating FAIMS at a few discrete values of CV rather than scanning CV across a wide range. The ability to reduce scanning requirements has potential benefits for coupling FAIMS with LC-MS. In select cases, FAIMS can be used to eliminate isobaric MS overlap between tryptic peptides; however, the primary advantage of FAIMS in an LCFAIMS-MS analysis is foreseen to be the attenuation of chemical background noise rather than the separation of individual peptides. Using FAIMS to reduce mass spectral noise will offer improved detection of peptides from low abundance proteins in complex biological samples. (J Am Soc Mass Spectrom 2002, 13, 1282-1291) (C) 2002 American Society for Mass Spectrometry
\end{abstract}

$\mathrm{E}$ lectrospray ionization (ESI) of protein digests is commonly coupled with capillary column liquid chromatography and tandem mass spectrometry [1]. Although protein digests can be analyzed directly, ESI is characteristically intolerant of the high levels of salts and detergents associated with excised sodium dodecylsulfate polyacrylamide gel electrophoresis (SDS-PAGE) bands. Reverse-phase LC provides the desalting necessary for high-sensitivity ESI-MS/MS of tryptic peptides. Improved MS analysis of tryptic peptides may also be achieved by processing the ESI ion cloud before introduction to the mass spectrometer. Presently, there are two predominant technologies capable of separating gas-phase ions from an ESI source prior to MS sampling and analysis: Drift-tube ion mobility spectrometry (DTIMS) [2-9] and high-field asymmetric waveform ion mobility spectrometry (FAIMS) [10-14]. Recent studies combining HPLC with DTIMS-MS for the analysis of peptide mixtures $[15,16]$ show that the extra dimension of separation provided by DTIMS reduces mass spectral congestion by separating peptides (according to drift time) into "charge-state

Published online September 25, 2002

Address reprint requests to Dr. D. A. Barnett, Ionalytics Corporation, Building M-50-IPF, 1200 Montreal Road, Ottawa K1A 0R6, Ontario, Canada. E-mail: david.barnett@ionalytics.com families". DTIMS can be combined with LC-MS because of sizable differences in the widths of LC elution profiles (seconds), IMS drift times (milliseconds), and time-of-flight MS (microseconds) analysis [16].

FAIMS is a gas-phase ion separation technique that, when used in conjunction with ESI, significantly lowers detection limits for tryptic peptides $[13,14]$ by reducing background ion current. The separation of ions by FAIMS is based on compound-dependent differences in an ion's mobility at high-field $\left(\mathrm{K}_{\mathrm{h}}\right)$ relative to low-field (K) [18]; deviations in ion mobility resulting from the high electric fields are reflected experimentally by the compensation voltage (CV) of transmission for a particular analyte. Ion transmission through a FAIMS device is high because of a unique ion focusing mechanism [17]. In a FAIMS experiment, the CV of optimal transmission is determined by scanning a selected $\mathrm{CV}$ range while monitoring the $\mathrm{m} / \mathrm{z}$ of the ion(s) of interest. Since no model currently exists to predict an analyte's CV of transmission, this scanning may be a limitation in experiments (such as the analysis of protein digests) where FAIMS is coupled with a condensed phase separation technique that introduces ions to the FAIMS-MS system in discrete pulses. More specifically, a limitation may arise from the finite transit or "residence" time of ions within the FAIMS device. Since ions are transported through FAIMS by the gas flow into the 
MS, the residence time is determined by the volume of the device and the pumping capacity of the vacuum system. When the CV is changed, some ions within the device are discharged to the electrode surfaces. For the FAIMS-MS system described here, approximately 180 ms are required for a new batch of ions, transmitted using the new CV condition, to arrive at the MS orifice. For a CV scan over a $40 \mathrm{~V}$ range in $0.5 \mathrm{~V}$ increments, the time required just to replenish ions within the FAIMS device (i.e., not including the time for MS measurement) is in excess of $14 \mathrm{~s}$. The addition of FAIMS to an LC-MS system is predicted to diminish the mass spectrometer's ability to fully interrogate the LC separation. In preparation for LC-FAIMS-MS analysis of peptide mixtures, it is therefore necessary to study the transmission characteristics of a large number of tryptic peptides. In this study, compensation voltage (CV) maps for 282 tryptic peptides from thirteen proteins were generated based on charge-state, mass-to-charge ratios, and chain length. A majority of tryptic peptides can be detected using an LC-FAIMS-MS experiment in which the $\mathrm{CV}$ is stepped between a few values rather than scanned across a wide range.

\section{Experimental}

The dome-version FAIMS design used in this study [13] consisted of two concentric stainless steel cylinders mounted inside a polyetheretherketone (PEEK) housing and secured to the orifice of a triple-quadrupole mass spectrometer. A custom-built waveform generator was used to deliver both the dispersion voltage (DV) and compensation voltage $(\mathrm{CV})$ to the inner cylinder (16-mm o.d.) of the FAIMS device. The asymmetric waveform was composed of a 2:1 ratio of a $750 \mathrm{kHz}$ sinusoidal wave and its first harmonic (i.e., $1.5 \mathrm{MHz}$ ) with a maximum voltage (i.e., DV) of $-4000 \mathrm{~V}$. The CV was provided to the waveform generator using the "OR" voltage source from the API-300 mass spectrometer (PE/Sciex). This enabled the use of the "scan parameter" function in the LCTune1.4 (PE/Sciex) software package for acquiring compensation voltage scans. A constant dc bias of $40 \mathrm{~V}$ was applied to the outer cylinder (20-mm i.d.) of the FAIMS device and to the orifice plate of the mass spectrometer using a Xantrax $120 \mathrm{~V}$ dc power supply (Allan Crawford and Associates, Ottawa, ON). The entire FAIMS electrode assembly, including the PEEK housing was approximately $10 \mathrm{~cm}$ long and $5 \mathrm{~cm}$ in diameter.

Ions from the electrospray source $(4400 \mathrm{~V}, 180 \mathrm{nA})$, which was positioned roughly $1 \mathrm{~cm}$ from a $2 \mathrm{~mm}$ orifice in a brass curtain plate $(1000 \mathrm{~V})$, passed through the curtain region and entered the FAIMS device through a $1 \mathrm{~mm}$ aperture in the outer cylinder. Variable flows of industrial grade nitrogen and helium (Air Products, Ottawa, ON) were passed through separate charcoal/ molecular sieve filters, combined in a tee assembly, and introduced into the gap $(\sim 1.5 \mathrm{~mm})$ between the curtain plate and the outer cylinder at a combined flow rate of
$2 \mathrm{~L} / \mathrm{min}$. The majority of this gas exited through the curtain plate countercurrent to the ESI-generated ions, aiding in their desolvation. The remainder of the gas was drawn into the FAIMS analyzer, carrying the ions along the length of the cylinders and into the orifice of the mass spectrometer. Individual gas-flows were adjusted using mass flow meters (MKS Type 1179A) connected to an MKS Type 247D four-channel readout (MKS Instruments, Andover, MA). Using appropriate combinations of DV and CV, ions could be selectively transmitted through the FAIMS device, focused to a region in front of the spherical tip of the inner cylinder, and sampled by the mass spectrometer. The path length for ion transport through the FAIMS device was approximately $3 \mathrm{~cm}$.

Tryptic digests of enolase 1 , cytochrome C, bovine albumin, sheep albumin, dog albumin, pig albumin, horse albumin, alcohol dehydrogenase, sheep hemoglobin, glucose oxidase, bovine hemoglobin, creatine phosphokinase, and conalbumin were provided as individual lyophilized powders by Professor David Clemmer of Indiana University (Bloomington, IN) [19]. Stock solutions of each digest were prepared at approximately $1 \mathrm{mg} / \mathrm{mL}$ in distilled, deionized water and stored at $-20{ }^{\circ} \mathrm{C}$. Individual samples for analysis (see Table 1 for details) were prepared in fresh solutions containing 50/49/1 (vol/vol/vol) methanol/water/ acetic acid immediately prior to use. Note that sample concentrations are stated per digest and may not reflect the concentration of any individual peptide within the digest.

\section{Results and Discussion}

\section{FAIMS Transmission of Tryptic Fragments}

The CV required for ion transmission through a FAIMS device is a reflection of the deviation in the ion mobility ratio $\left(\mathrm{K}_{\mathrm{h}} / \mathrm{K}\right)$ that results from the changing electric fields. Although a limited correlation between the $\mathrm{CV}$ and both the mass and charge state of gas-phase tryptic peptides has been shown [13], the CV of optimal transmission of each peptide must be determined experimentally. For a complex mixture containing several peptides, this is readily accomplished by collecting a total-ion-current compensation voltage (TIC-CV) spectrum. Acquisition of a TIC-CV spectrum involves collecting mass spectra while scanning the $\mathrm{CV}$ over a wide voltage range. Figure 1a shows a TIC-CV spectrum collected for an $11 \mathrm{ng} / \mu \mathrm{L}$ tryptic digest of enolase 1 (baker's yeast). For this experiment, the CV was scanned from -1.0 to $-19.7 \mathrm{~V}$ at a DV of $-4000 \mathrm{~V}$ in a carrier gas of nitrogen. Each of the 201 points in this plot (CV step of $\sim 0.09 \mathrm{~V}$ ) represents the summed ion current for an $m / z$ range of 200-1000. Each mass spectrum was collected in 0.2 am $\mu$ increments using a dwell time of 5 ms. Acquisition of the complete TIC-CV spectrum using the triple-quadrupole mass spectrometer required a total of $67 \mathrm{~min}$, however, this analysis time can be 
Table 1. Samples for Analysis

\begin{tabular}{lllr}
\hline Protein & \multicolumn{1}{c}{ Source } & $\begin{array}{c}\text { Stock } \\
\text { Concentrations } \\
(\mathrm{mg} / \mathrm{mL})\end{array}$ & $\begin{array}{c}\text { Sample } \\
\text { concentrations } \\
(\mathrm{ng} / \mu \mathrm{L})\end{array}$ \\
\hline \hline Enolase 1 & Baker's yeast & 3.8 & 11 \\
Cytochrome C & Horse heart & 1.8 & 9 \\
Albumin & Bovine & 1.7 & 17 \\
Albumin & Dog & 5.0 & 15 \\
Albumin & Pig & 0.88 & 18 \\
Albumin & Sheep & 0.6 & 12 \\
Albumin & Horse & 1.6 & 16 \\
Alcohol dehydrogenase & Baker's yeast & 0.68 & 14 \\
Hemoglobin (alpha) & Sheep & 0.92 & 9 \\
Hemoglobin (beta) & Sheep & 0.29 & 11 \\
Glucose oxidase & Aspergillus Niger & & 14 \\
Hemoglobin (alpha) & Bovine & 0.7 & 7 \\
Hemoglobin (beta) & Bovine & 0.7 & 1.12 \\
Creatine phosphokinase & Rabbit Muscle & & \\
Conalbumin & Chicken egg white & & 1 \\
\hline
\end{tabular}
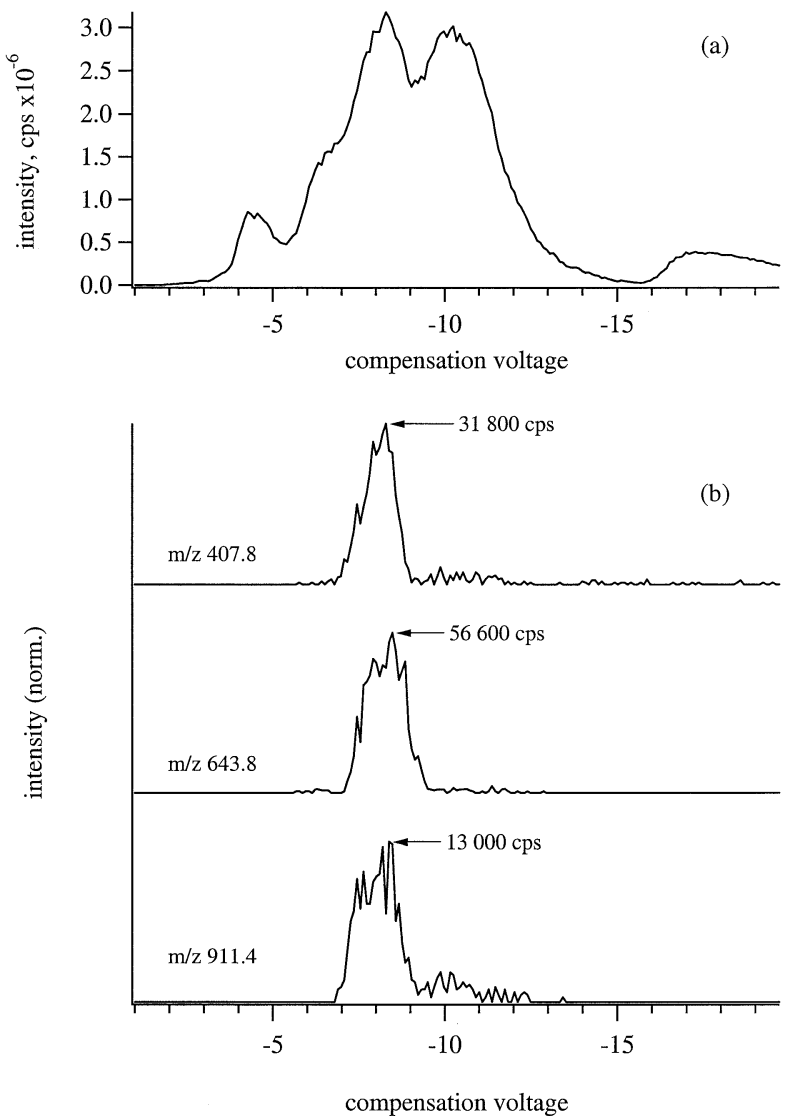

Figure 1. ESI-FAIMS-MS of a $11 \mathrm{ng} / \mu \mathrm{L}$ solution of a tryptic digest of enolase 1 (baker's yeast): (a) TIC-CV spectrum acquired for an $m / z$ range of 200-1000 at a DV of $-4000 \mathrm{~V}$ in nitrogen and (b) IS-CV spectra derived by extracting the ion current for $\mathrm{m} / \mathrm{z}$ values of $407.8,643.8$, and 911.4 from (a). The $\mathrm{M}^{2+}$ peptides at these $\mathrm{m} / \mathrm{z}$ values have sequences of AADALLLK, NVNDVIAPAFVK, and SGETEDTFIADLVVGLR, respectively.
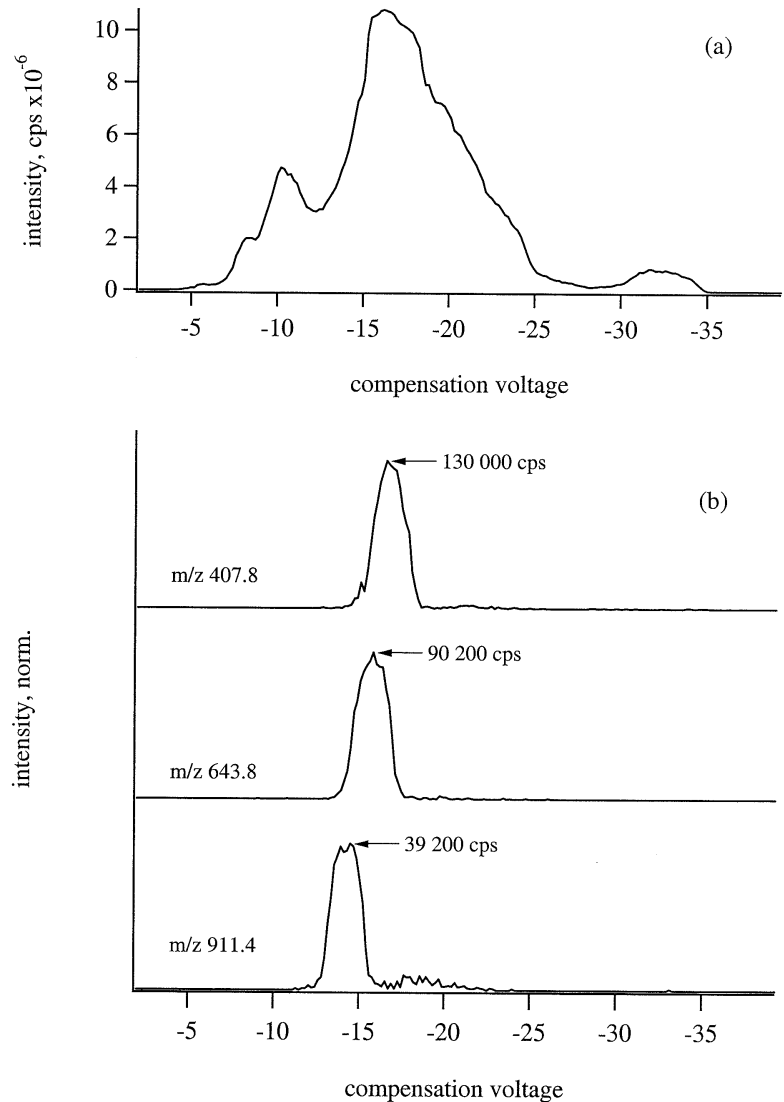

Figure 2. ESI-FAIMS-MS of a $11 \mathrm{ng} / \mu \mathrm{L}$ solution of a tryptic digest of enolase 1 (baker's yeast): (a) TIC-CV spectrum acquired for an $m / z$ range of $200-1000$ at a DV of $-4000 \mathrm{~V}$ in $1: 1 \mathrm{He} / \mathrm{N}_{2}$ and (b) IS-CV spectra derived by extracting the ion current for $\mathrm{m} / \mathrm{z}$ values of $407.8,643.8$, and 911.4 from (a). The $\mathrm{M}^{2+}$ peptides at these $\mathrm{m} / \mathrm{z}$ values have sequences of AADALLLK, NVNDVIAPAFVK, and SGETEDTFIADLVVGLR, respectively. 
Table 2. Comparison of relative intensities observed for 26 doubly-charged peptide ions from a tryptic digest of Enolase 1 (baker's yeast) using ESI-MS, ESI-FAIMS-MS (DV $-4000 \mathrm{~V}$, nitrogen carrier gas) and ESI-FAIMS-MS (DV of $-4000 \mathrm{~V} ; 1: 1 \mathrm{He} / \mathrm{N}_{2}$ carrier gas)

\begin{tabular}{|c|c|c|c|c|}
\hline Peptide & $\begin{array}{c}m / z \\
z=+2\end{array}$ & $\begin{array}{c}\text { Intensity } \\
\text { ESI-MS }\end{array}$ & $\begin{array}{c}\text { Intensity } \\
\text { ESI-FAIMS-MS } \\
\mathrm{N}_{2}\end{array}$ & $\begin{array}{c}\text { Intensity } \\
\text { ESI-FAIMS-MS } \\
1: 1 \mathrm{He}^{\prime} \mathrm{N}_{2}{ }^{*} \\
\end{array}$ \\
\hline VYAR & 254.6 & $\mathrm{nd}^{* *}$ & nd & 70800 \\
\hline WMGK & 261.1 & nd & nd & 57600 \\
\hline TGOIK & 273.8 & nd & nd & 149600 \\
\hline AAAAEK & 280.6 & nd & nd & 71600 \\
\hline TGAPAR & 286.8 & nd & nd & 10200 \\
\hline AAGHDGK & 328.2 & 15600 & 14000 & $36200(2.3)$ \\
\hline ANIDVK & 330.2 & nd & nd & 215000 \\
\hline NPNSDK & 337.6 & nd & nd & 89400 \\
\hline GVLHAVK & 362.2 & 6200 & 34400 & $73400(11.8)$ \\
\hline SVYDSR & 363.8 & nd & 7000 & 67400 \\
\hline NVPLYK & 367.2 & nd & nd & 114600 \\
\hline IATAIEK & 373.4 & 35400 & 37200 & $163000(4.6)$ \\
\hline LNQLLR & 378.8 & 41700 & 79200 & $341400(8.2)$ \\
\hline HLADLSK & 392.2 & 110600 & 131400 & $269000(2.4)$ \\
\hline YDLDFK & 400.7 & nd & 8600 & 58600 \\
\hline TFAEALR & 404.4 & 50600 & 50400 & $221600(4.4)$ \\
\hline AADALLLK & 407.8 & 24300 & 31800 & $130000(5.3)$ \\
\hline IGSEVYHNLK & 580.2 & 13400 & 11600 & $15800(1.2)$ \\
\hline NVNDVIAPAFVK & 643.8 & 50300 & 56600 & $90200(1.8)$ \\
\hline VNOIGTLSESIK & 644.8 & 67200 & 51200 & $119000(1.8)$ \\
\hline LGANAILGVSLAASR & 706.8 & 27600 & 13600 & $50600(1.8)$ \\
\hline GNPTVEVELTTEK & 708.8 & 36000 & 17600 & $83400(2.3)$ \\
\hline AVDDFLISLDGTANK & 789.8 & 38700 & 21600 & $102400(2.6)$ \\
\hline TAGIQIVADDLTVTNPK & 878.8 & 42600 & 21000 & $47000(1.1)$ \\
\hline SGETEDTFIADLVVGLR & 911.4 & 29200 & 13000 & $39200(1.3)$ \\
\hline SIVPSGASTGVHEALEMR & 921.0 & nd & 5600 & 12400 \\
\hline
\end{tabular}

*Bracketed values indicate ratio of ESI-FAIMS-MS to ESI-MS intensity for individual peptides

${ }^{*}$ nd $=$ not detected

greatly reduced using a time-of-flight instrument [14]. Electrospray ionization of a tryptic peptide solution produces a complex mixture of gas-phase ions, the majority of which are often not directly related to the digested protein, especially for dilute samples. Therefore, even though the TIC-CV spectrum contains five discernible peaks located at $\mathrm{CV}$ values of $-4.5 \mathrm{~V},-7.0$ $\mathrm{V},-8.3 \mathrm{~V},-11.0 \mathrm{~V}$ and $-18.0 \mathrm{~V}$, these peaks are not attributable to any individual ion or types of ions (other than ions having similar $\mathrm{K}_{\mathrm{h}} / \mathrm{K}$ values for the given set of conditions). A mass spectrum acquired at any particular $\mathrm{CV}$ value will represent a subset of the complex ion mixture produced by ESI. Individual peptides can be identified by examining mass spectra collected at individual CV values. Subsequently, the optimum transmission voltage for an individual tryptic peptide can be determined from the TIC-CV spectrum by extracting the ion-current for a specific $m / z$ to generate an ion-selective compensation voltage (IS-CV) spectrum. Figure $1 \mathrm{~b}$ shows IS-CV spectra for three doublycharged tryptic peptides of enolase 1 having $m / z$ values of $407.8,643.8$, and 911.4. These $\mathrm{m} / \mathrm{z}$ values correspond to the peptide sequences AADALLLK, NVNDVIAPAFVK, and SGETEDTFIADLVVGLR, respectively. The optimal transmission of each of these three ions $(\mathrm{CV}$ of $\sim-7.5 \mathrm{~V}$ ) resulted in signal intensities of 31,800 cps, 56,600 cps, and 13,000 cps, respectively. For the conditions used in this experiment, most of the doublycharged tryptic peptides of enolase 1 were transmitted at or near a CV of $-7.5 \mathrm{~V}$.

The CV required for optimal ion transmission is dependent on several parameters, including the magnitude of the DV [10], the shape of the applied asymmetric waveform [20], the width of the FAIMS analyzer region, and the pressure, temperature, and composition of the carrier gas [21-25]. Previous studies have highlighted the advantages of using a carrier gas composed of a mixture of nitrogen and helium for ions having $\mathrm{K}_{\mathrm{h}} / \mathrm{K}<1$ in nitrogen (e.g., the peptides in Figure 1) [24, 25]. A detailed quantitative study [22] of morphine and codeine by FAIMS showed that the addition of helium to a nitrogen based carrier gas causes dramatic increases in both CV and signal intensity. Optimal results were obtained at maximum helium content, the value of which is limited by three factors: (1) Electrical discharge initiated at the ESI source, (2) electrical discharge initiated by the high fields within FAIMS, and (3) practical limits in the pumping capacity of the mass spectrometer vacuum system. The use of a $1: 1 \mathrm{He} / \mathrm{N}_{2}$ carrier gas mixture is a compromise between increased analytical performance and system stability. Figure 2a shows a TIC-CV spectrum $(\mathrm{CV}=-2.0$ to $-39.3 \mathrm{~V})$ collected for the same $11 \mathrm{ng} / \mu \mathrm{L}$ solution of enolase 1 digest as in Figure 1 , using a carrier gas containing $1: 1 \mathrm{He} / \mathrm{N}_{2}$. Each 
Table 3. Comparison of S/B for 26 doubly-charged peptide ions from a tryptic digest of Enolase 1 (baker's yeast) using ESI-FAIMSMS (DV of $-4000 \mathrm{~V} ; 1: 1 \mathrm{He} / \mathrm{N}_{2}$ ) and ESI-MS

\begin{tabular}{|c|c|c|c|c|c|}
\hline Peptide & $m / z z=+2$ & $\begin{array}{l}\text { CV } \\
\text { (V) } \\
\end{array}$ & $\begin{array}{c}\text { S/B } \\
\text { ESI-FAIMS-MS } \\
1: 1 \mathrm{He} / \mathrm{N}_{2} \\
\end{array}$ & $\begin{array}{c}\text { S/B } \\
\text { ESI-MS }\end{array}$ & S/B increase \\
\hline VYAR & 254.6 & -10.2 & 54 & $\mathrm{nd}^{*}$ & \\
\hline WMGK & 261.1 & -13.0 & 54 & nd & \\
\hline TGQIK & 273.8 & -16.7 & 161 & nd & \\
\hline AAAAEK & 280.6 & -17.9 & 94 & nd & \\
\hline TGAPAR & 286.8 & -18.6 & 9.4 & nd & \\
\hline AAGHDGK & 328.2 & -19.3 & 40 & nd & \\
\hline ANIDVK & 330.2 & -16.7 & 168 & nd & \\
\hline NPNSDK & 337.6 & -22.9 & 147 & nd & \\
\hline GVLHAVK & 362.2 & -15.6 & 58 & 3.2 & 18 \\
\hline SVYDSR & 363.8 & -17.9 & 82 & nd & \\
\hline NVPLYK & 367.2 & -16.7 & 127 & 6.0 & 21 \\
\hline IATAIEK & 373.4 & -17.8 & 198 & 6.9 & 29 \\
\hline LNQLLR & 378.8 & -16.9 & 310 & 8.3 & 37 \\
\hline HLADLSK & 392.2 & -32.5 & 259 & 22 & 12 \\
\hline YDLDFK & 400.7 & -20.2 & 69 & nd & \\
\hline TFAEALR & 404.4 & -22.5 & 302 & 10.1 & 30 \\
\hline AADALLLK & 407.8 & -16.5 & 108 & 4.9 & 22 \\
\hline IGSEVYHNLK & 580.2 & -15.3 & 16 & 4.0 & 4 \\
\hline NVNDVIAPAFVK & 643.8 & -15.8 & 74 & 9.6 & 11 \\
\hline VNQIGTLSESIK & 644.8 & -17.2 & 76 & 13 & 6 \\
\hline LGANAILGVSLAASR & 706.8 & -14.7 & 48 & 8.6 & 6 \\
\hline GNPTVEVELTTEK & 708.8 & -16.2 & 50 & 9.8 & 5 \\
\hline AVDDFLISLDGTANK & 789.8 & -15.3 & 55 & 9.3 & 6 \\
\hline TAGIQIVADDLTVTNPK & 878.8 & -13.4 & 60 & 9.6 & 6 \\
\hline SGETEDTFIADLVVGLR & 911.4 & -14.5 & 31 & 7.6 & 4 \\
\hline SIVPSGASTGVHEALEMR & 921.0 & -11.9 & 23 & nd & \\
\hline
\end{tabular}

${ }^{*} \mathrm{nd}=$ not detected

of the 201 points in this plot (CV step of $\sim 0.18 \mathrm{~V}$ ) represents the summed ion current for an $\mathrm{m} / \mathrm{z}$ range of 200-1000. Each mass spectrum was collected in $0.2 \mathrm{am} \mu$ increments using a dwell time of $5 \mathrm{~ms}$. Aside from changes to the carrier gas and $\mathrm{CV}$ scan range, all instrumental parameters were kept constant compared with those used in collecting the data shown in Figure 1. The carrier gas of 1:1 He/ $\mathrm{N}_{2}$ had a dramatic effect on the transmission of the tryptic peptides. Extracted IS-CV plots for the three peptide ions, Figure $2 b$, show significant differences in $\mathrm{CV}$ and intensity compared with those of Figure 1b. The optimal CV for transmission of AADALLLK ${ }^{2+}$ increased to $-16.5 \mathrm{~V}$ in the mixed carrier gas and was accompanied by a 4 -fold increase in intensity to $130000 \mathrm{cps}$ (all ions are of the form $[\mathrm{M}+n \mathrm{H}]^{n+}$, but for clarity throughout this document are given as $\mathrm{M}^{\mathrm{n}+}$ ). The doubly-charged ions of NVNDVIAPAFVK and SGETEDTFIADLVVGLR experienced similar increases in $\mathrm{CV}$; the intensities of their IS-CV peaks were 2.5- and 3-fold higher, respectively.

In all, 26 doubly-charged tryptic fragments of enolase 1 were identified from the TIC-CV spectrum acquired when the carrier gas was $1: 1 \mathrm{He} / \mathrm{N}_{2}(53 \%$ sequence coverage) compared with just 18 when the carrier gas was pure nitrogen ( $44 \%$ sequence coverage). The sequence coverage obtained by analyzing this same solution by ESI-MS (using the same instrumental con- ditions) was $37 \%$. Table 2 gives a summary of the intensities observed for the doubly-charged peptides of enolase 1 by ESI-MS and ESI-FAIMS-MS. Of the 15 peptides that could be assigned by ESI-MS, FAIMS offered an average intensity gain of greater than three and concomitant reductions in background of greater than five when using a DV of $-4000 \mathrm{~V}$ and a carrier gas of $1: 1 \mathrm{He} / \mathrm{N}_{2}$. The additional 11 peptides that were identified using ESI-FAIMS-MS are also presented. As detection of peptide fragments by ESI-MS is ultimately limited by the intense chemical background, the criterion used for peptide identification was a minimum $\mathrm{S} / \mathrm{B}$ of three in the first-order MS scans. Table 3 provides a summary of the S/B values for the peptides from each method, and an indication of the relative improvement offered by FAIMS.

Plots of $\mathrm{m} / \mathrm{z}$ versus CV of transmission for all of the doubly-charged tryptic peptides of enolase 1 identified using a carrier gas of nitrogen are shown in Figure 3a, while those identified using the mixed carrier gas are shown in Figure $3 \mathrm{~b}$. The bars indicate the full-width at half maximum (FWHM) of each CV peak, in units of volts. For a carrier gas of nitrogen, most of the doublycharged peptides of enolase 1 were transmitted at or near a CV value of $-7.5 \mathrm{~V}$, while in the $1: 1 \mathrm{He} / \mathrm{N}_{2}$ carrier gas the majority of $\mathrm{z}=+2$ peptides were transmitted near a $C V$ value of $-15.5 \mathrm{~V}$. On average, the 

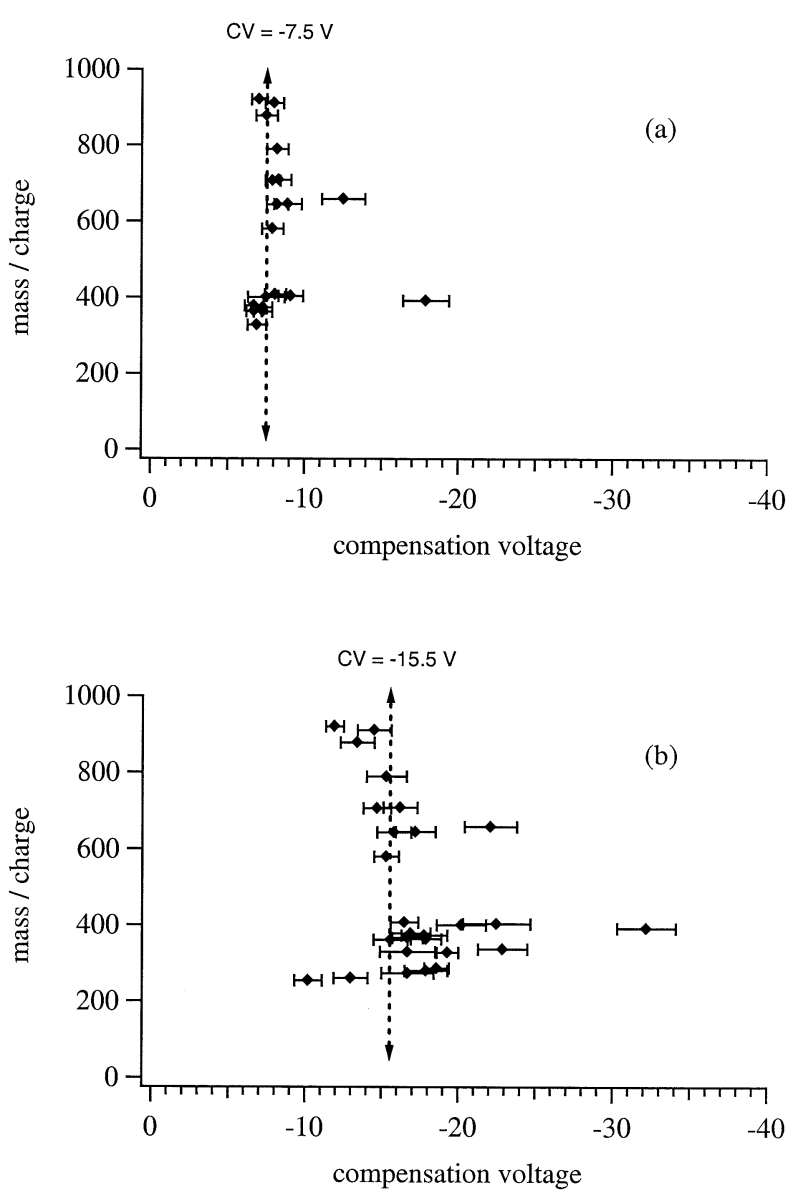

Figure 3. Summary plots of $m / z$ as a function of compensation voltage for all of the identified $\mathrm{M}^{2+}$ peptide ions of enolase 1 in carrier gases of (a) nitrogen and (b) 1:1 He/ $\mathrm{N}_{2}$. The bars represent the CV peak width (FWHM) for each of the peptide ions.

width (FWHM) of a CV peak for a doubly-charged peptide with optimal transmission at $\mathrm{CV}=-15.5 \mathrm{~V}$ is $2.5 \mathrm{~V}$. Therefore if the FAIMS device is operated in continuous mode at a $\mathrm{CV}$ of $-15.5 \mathrm{~V}$, ions having optimal CVs ranging from about $-14.3 \mathrm{~V}$ to $-16.7 \mathrm{~V}$ will be transmitted with at least $50 \%$ of their optimal transmission efficiency. The dashed lines in Figure 3a and $b$ illustrate that at selected $C V$ values in either gas composition, many of the doubly-charged peptides of enolase 1 can be transmitted with at least $50 \%$ efficiency relative to that observed at their individually optimized $\mathrm{CVs}$. The transmission of a significant fraction of the doubly-charged tryptic peptides at a single $\mathrm{CV}$ value (or a limited number of CVs) will offer advantages when FAIMS is coupled with separation techniques such as $\mu$-LC or capillary electrophoresis.

\section{Values of Peptide Ions from 13 Protein Digests}

Total-ion-current compensation voltage spectra $(\mathrm{m} / \mathrm{z}$ 200 to 1000) were collected for thirteen separate tryptic protein digests using a carrier gas of $1: 1 \mathrm{He} / \mathrm{N}_{2}(\mathrm{DV}=$ $-4000 \mathrm{~V})$. The identities and concentrations of the
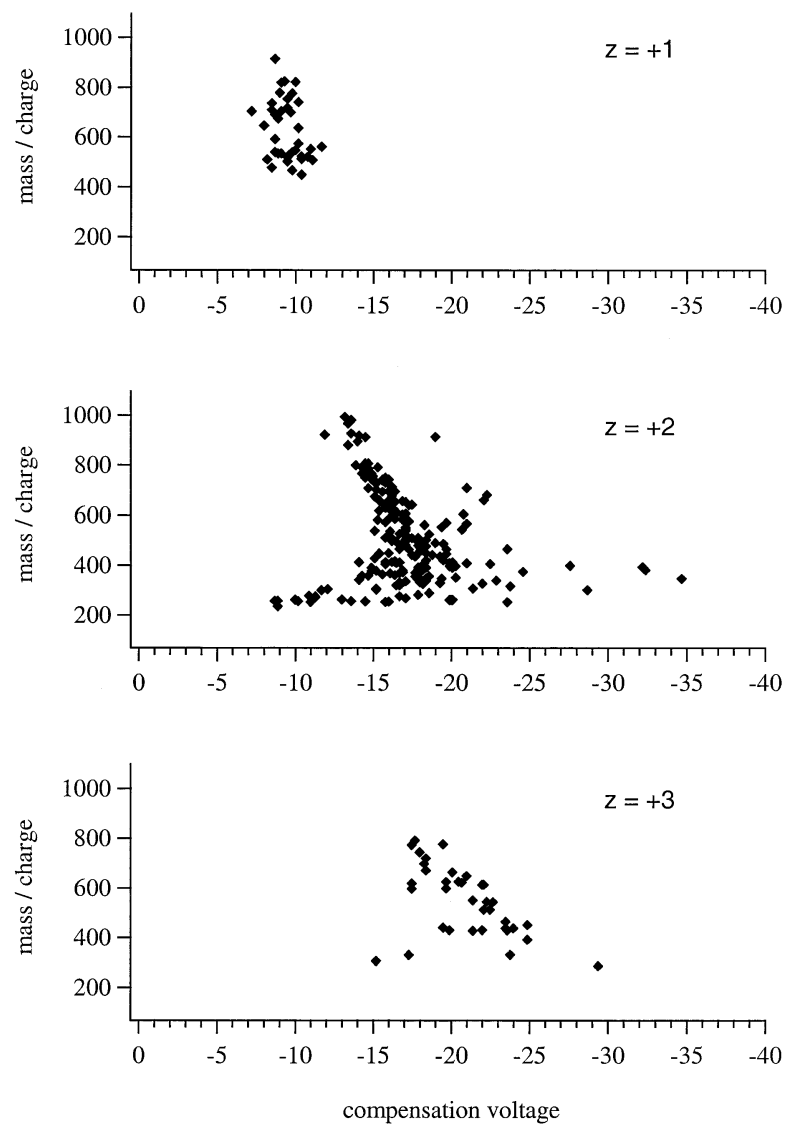

Figure 4. Summary plots of $\mathrm{m} / \mathrm{z}$ as a function of compensation voltage for (a) 38 singly-, (b) 208 doubly-, and (c) 36 triply-charged peptide ions from 13 protein digests in a $1: 1 \mathrm{He} / \mathrm{N}_{2}$ gas at $\mathrm{DV}=$ $-4000 \mathrm{~V}$.

protein digest mixtures are listed in Table 1. From these TIC-CV spectra, 38 singly-charged, 208 doubly-charged, and 36 triply-charged peptide fragment ions were identified using a minimum S/B threshold of three. Figure 4 shows a plot of $\mathrm{m} / \mathrm{z}$ as a function of CV for all of the 282 identified ions, segregated on the basis of charge state. These results show that the singly-charged ions tend to be transmitted near a $\mathrm{CV}$ of $-9 \mathrm{~V}$, whereas the $\mathrm{CV}$ values for the doubly- and triply-charged ions are considerably more varied. Despite the scatter in the data for the doubly (i.e., $z=+2$ ) charged tryptic fragments, the majority of $\mathbf{z}=+2$ peptides with $\mathrm{m} / \mathrm{z}$ $>400$ were transmitted between $C V$ values of -13 and $-17 \mathrm{~V}$, with a tendency toward lower $\mathrm{CV}$ (i.e., $\mathrm{CV}=$ $-13 \mathrm{~V}$ ) with increasing $\mathrm{m} / \mathrm{z}$ ratio. In fact, 182 of the 208 $(88 \%)$ doubly-charged peptides identified were transmitted optimally between $C V$ values of -13 and $-22 \mathrm{~V}$, with the average FWHM of the CV peaks of $2.5 \mathrm{~V}$. Therefore, the collection of mass spectra at $4 \mathrm{CVs}$ across this $9.0 \mathrm{~V}$ range would be expected to yield over $85 \%$ of the doubly-charged peptides in a mixture.

The influence of the number of amino acid residues on ion transmission through FAIMS has also been investigated. Figure 5 shows plots of $\mathrm{m} / \mathrm{z}$ as a function of compensation voltage for the 208 doubly-charged 

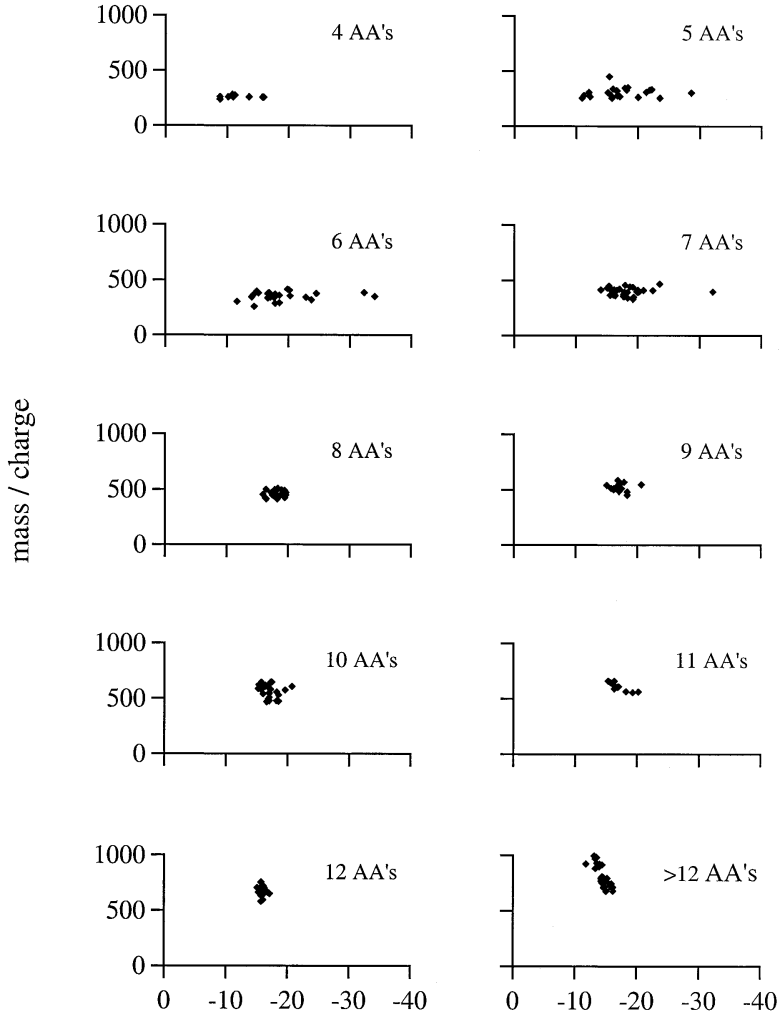

compensation voltage

Figure 5. Summary plots of $\mathrm{m} / \mathrm{z}$ as a function of compensation voltage for the doubly-charged peptide ions derived from 13 separate proteins. The ions have been segregated according to the number of amino acid residues in the peptide.

peptides, separated according to the number of residues comprising each peptide. The highest degree of variability in FAIMS transmission is observed in the peptides having the smallest number of residues (i.e., $n \leq$ 7). As the number of residues increases, the $\mathrm{CV}$ values of transmission appear to cluster within a $6 \mathrm{~V}$ window between -14 and $-20 \mathrm{~V}$ (recall that in this region the FWHM of a CV peak is about $2.5 \mathrm{~V}$ ).

\section{FAIMS Resolution of Isobaric Overlaps}

Data from the FAIMS analysis of the thirteen protein digests also showed that separation of peptides having both inter- and intra-charge state isobaric overlaps may occur within the FAIMS device. Separation of intracharge state isobaric overlap was observed between the peptides AWSVAR ${ }^{2+}$ and VLTSAAK ${ }^{2+}$, where the ions were transmitted at CVs of $-34.7 \mathrm{~V}$ and $-19.4 \mathrm{~V}$, respectively $\left(\mathrm{DV}=-4000 \mathrm{~V}, 1: 1 \mathrm{He} / \mathrm{N}_{2}\right)$. Instances of separation of inter-charge state overlap, however, are more common. For example, enzymatic digestion of cytochrome c (horse heart) with trypsin resulted in a pair of peptide ions (MIFAGIK ${ }^{2+}$ and TGPNLH$\mathrm{GLFGR}^{3+}$ ) that, when ionized by ESI, produced an isobaric overlap at $\mathrm{m} / \mathrm{z}$ 390.2. Figure 6a shows a FAIMS
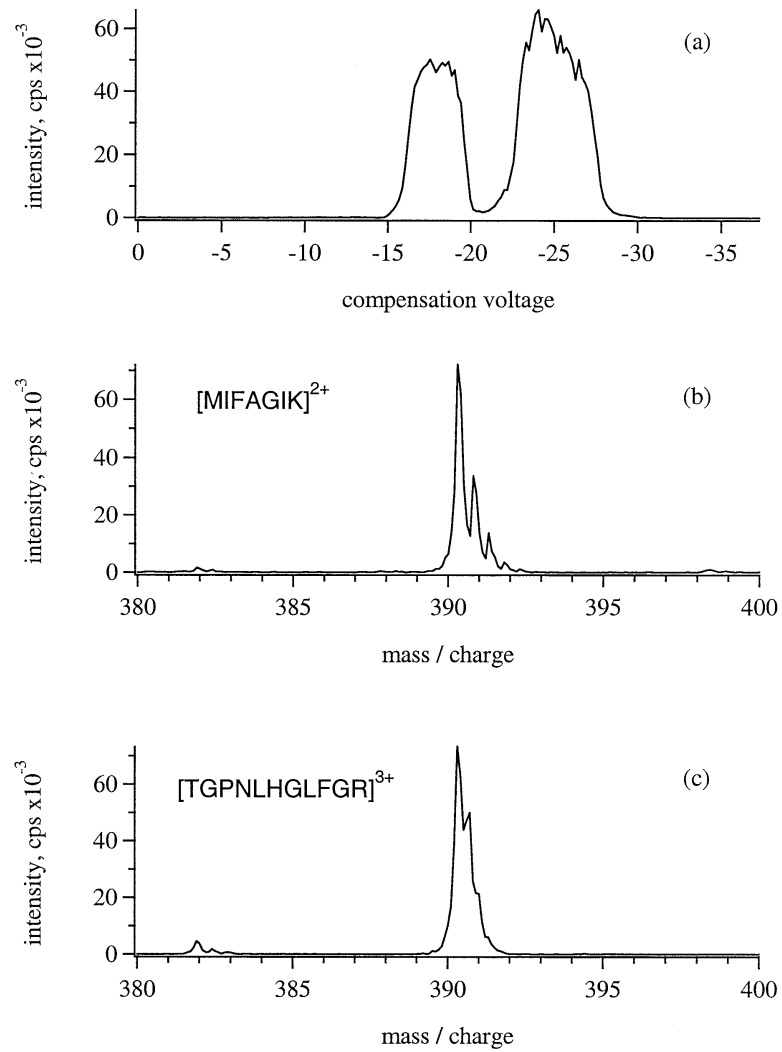

Figure 6. FAIMS separation of the $\mathrm{m} / \mathrm{z} 390.2$ isobaric overlap from a tryptic digestion of equine cytochrome c. (a) IS-CV spectra acquired for $m / z 390.2$ at $\mathrm{DV}=-4000 \mathrm{~V}$ in $1: 1 \mathrm{He} / \mathrm{N}_{2}$. ESI-FAIMS mass spectra acquired at $C V$ values of $(\mathbf{b})-17.9 \mathrm{~V}$ and $(\mathbf{c})-24.9 \mathrm{~V}$ showing characteristic isotopomer distributions for doubly- and triply-charged ions, respectively.

IS-CV spectrum for $\mathrm{m} / \mathrm{z} 390.2(\mathrm{DV}=-4000 \mathrm{~V}, 1: 1$ $\mathrm{He} / \mathrm{N}_{2}$ ) using a $9 \mathrm{ng} / \mu \mathrm{L}$ solution of the cytochrome $\mathrm{c}$ digest mixture. Mass spectra acquired at the CVs corresponding to the two peak maxima in Figure 6a (i.e., -17.9 $\mathrm{V}$ and $-24.9 \mathrm{~V})$ are shown in Figures $6 \mathrm{~b}$ and c, respectively. Each mass spectrum represents an average of 10 acquisitions over a limited mass range $(\mathrm{m} / \mathrm{z} 380-400)$ in $0.05 \mathrm{am} \mu$ increments. The dwell time per $0.05 \mathrm{am} \mu$ increment was $5 \mathrm{~ms}$. Transmission of the isobaric ions through the FAIMS device at different CVs is easily distinguished by the characteristic isotope distributions for $+2(0.5 \mathrm{Th})$ and $+3(0.33 \mathrm{Th})$ ions.

The use of ESI-MS/MS to characterize the $\mathrm{m} / \mathrm{z} 390.2$ from cytochrome $\mathrm{c}$ produces a tandem mass spectrum containing fragments of both peptides, as shown in Figure 7a. However, using FAIMS to separate these ions prior to conducting the MS/MS experiment produces fragmentation spectra that are characteristic of the individual +2 and +3 peptides as shown in Figures $7 \mathrm{~b}$ and c, respectively. Each MS/MS spectrum shown in Figure 7 represents an average of 10 acquisitions over an $\mathrm{m} / \mathrm{z}$ range of 30-1200 using a collisional energy of 32 $\mathrm{eV}$. Mass spectra were collected in 0.2 am $\mu$ increments using a dwell time per increment of $2 \mathrm{~ms}$. 

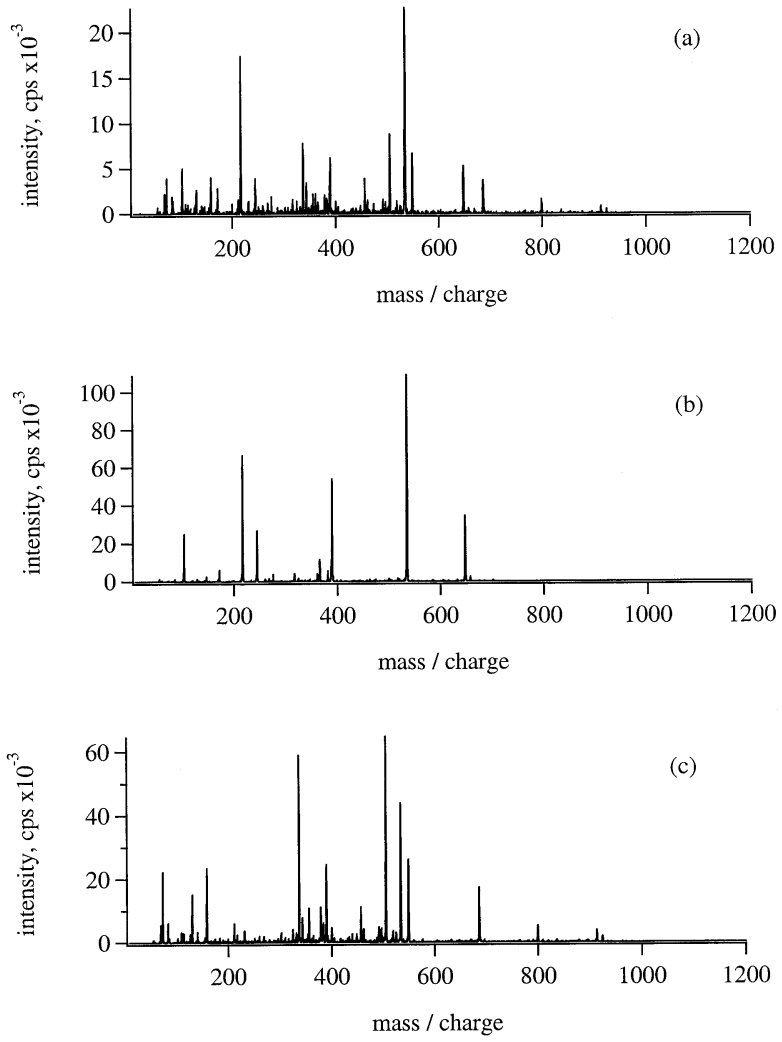

Figure 7. Tandem mass spectra acquired for $m / z 390.2$ from an equine cytochrome c tryptic digest using (a) ESI-MS/MS, and ESI-FAIMS-MS/MS at a CV of (b) $-17.9 \mathrm{~V}$ and (c) $-24.9 \mathrm{~V}$.

\section{Analysis of a Mixture of Six Protein Digests}

An analytical challenge in the identification of proteins is the development of methodology to simplify the characterization of individual proteins present in multicomponent mixtures. Conventional ESI mass spectra of unseparated mixtures of protein digests are difficult to interpret because of high chemical background and isobaric overlap among component peptides. In addition, the ionization efficiency of the peptides is reduced due to increased competition within the ESI process itself. Although FAIMS cannot reverse the effect of deteriorating ionization efficiency, the ability of FAIMS to filter out background ions (and in some cases separate isobaric overlap) is very valuable for this application. Figure 8 shows a comparison of ESI-MS with ESI-FAIMS-MS for the analysis of a mixture of six protein digests. The sample mixture was prepared post-digestion by combining $500 \mathrm{fmol} / \mu \mathrm{L}$ of each of the following tryptic digests: alcohol dehydrogenase, sheep albumin, sheep hemoglobin, conalbumin, creatine phosphokinase, and equine cytochrome c. The ESI-MS spectrum in Figures $8 \mathrm{a}$ is complex and has an elevated background across the entire mass range. The ESI-FAIMS mass spectra $(\mathrm{DV}=-4000 \mathrm{~V}, 1: 1$ $\mathrm{He} / \mathrm{N}_{2}$ ) shown in Figure $8 \mathrm{~b}, \mathrm{c}$, and d were collected at three $\mathrm{CV}$ values. At a CV of $-16.5 \mathrm{~V}$, Figure $8 \mathrm{~b}$, the mass spectrum was dominated by doubly-charged tryptic fragments, with the four most abundant pep-
ESI-MS
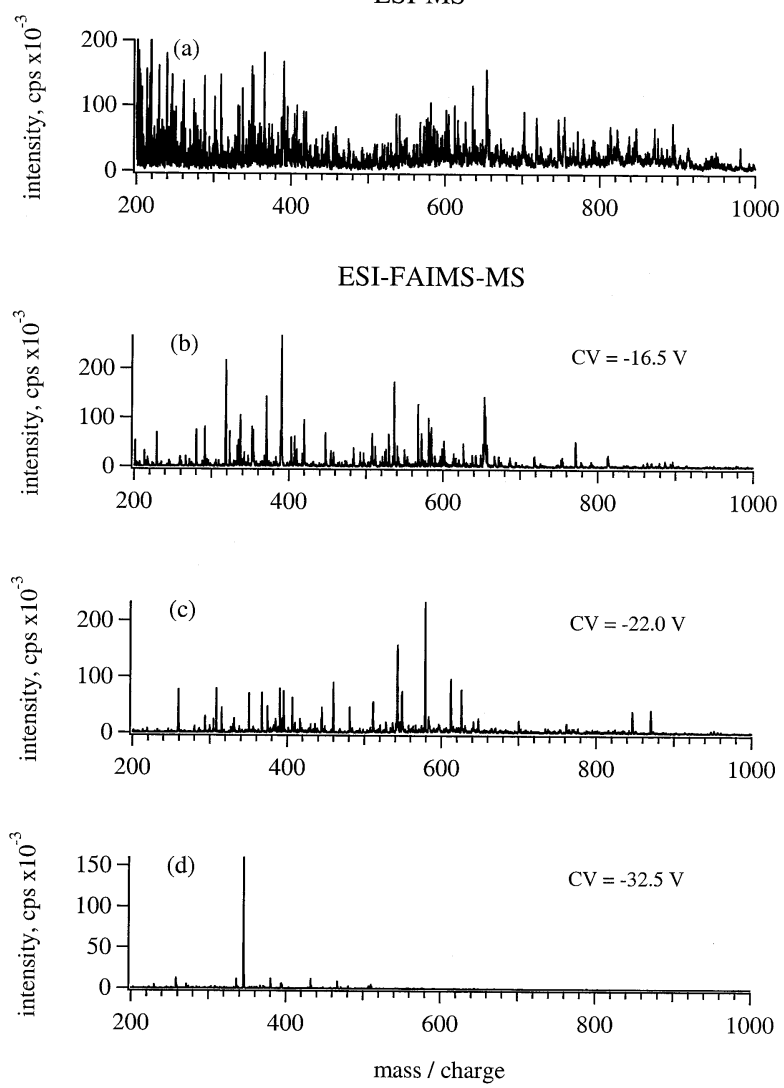

Figure 8. Comparison of ESI and ESI-FAIMS mass spectra acquired for a mixture of six tryptic digests. The sample mixture was prepared post-digestion, by combining $500 \mathrm{fmol} / \mu \mathrm{L}$ alcohol dehydrogenase, sheep albumin, sheep hemoglobin, conalbumin, creatine phosphokinase, and cytochrome c. With FAIMS, the DV was set to $-4000 \mathrm{~V}$, and the carrier gas contained $1: 1 \mathrm{He} / \mathrm{N}_{2}$.

tides at $\mathrm{m} / \mathrm{z}$ values of $318.2,390.2,536.4$, and 653.4, corresponding to $\mathrm{DLLFK}^{2+}$ (conalbumin), MIFAGIK ${ }^{2+}$ (equine cytochrome c), MFLSFPTTK ${ }^{2+}$ (sheep hemoglobin), and HLVDEPQHLIK ${ }^{2+}$ (sheep albumin), respectively. At $\mathrm{CV}=-22.0 \mathrm{~V}$ (Figure $8 \mathrm{c}$ ), the mass spectrum contained more multiply-charged peptide fragments (i.e., +3 and +4 ); the three most abundant ions had $\mathrm{m} / \mathrm{z}$ values of 543.1, 578.8, and 612.2 corresponding to KAPQVSTPTLVEISR ${ }^{3+}$ (sheep hemoglobin), AVGHLD DLPGTLSDLSDLHAHK $^{4+}$ (sheep albumin), and TYFPH FDLSHGSAQVK $^{3+}$ (sheep hemoglobin), respectively. Finally, the mass spectrum acquired at a CV of $-32.5 \mathrm{~V}$ (Figure 8d) was dominated by an ion with $\mathrm{m} / \mathrm{z}=345.2$ having a sequence of AWSVAR $^{2+}$ (sheep albumin). In each of the ESI-FAIMS mass spectra, the background ion intensity has been greatly reduced when compared with the ESI-MS spectrum, while the absolute intensities of the tryptic peptides are equal to, or greater than, those obtained by ESI-MS.

Figure 9 shows expanded views of the ESI-MS and ESI-FAIMS-MS (CV -16.5 V) mass spectra collected for the mixture of six protein digests over an $\mathrm{m} / \mathrm{z}$ range of 300 to 400 . By plotting the mass spectra over this narrow range, the relative intensity improvements and 

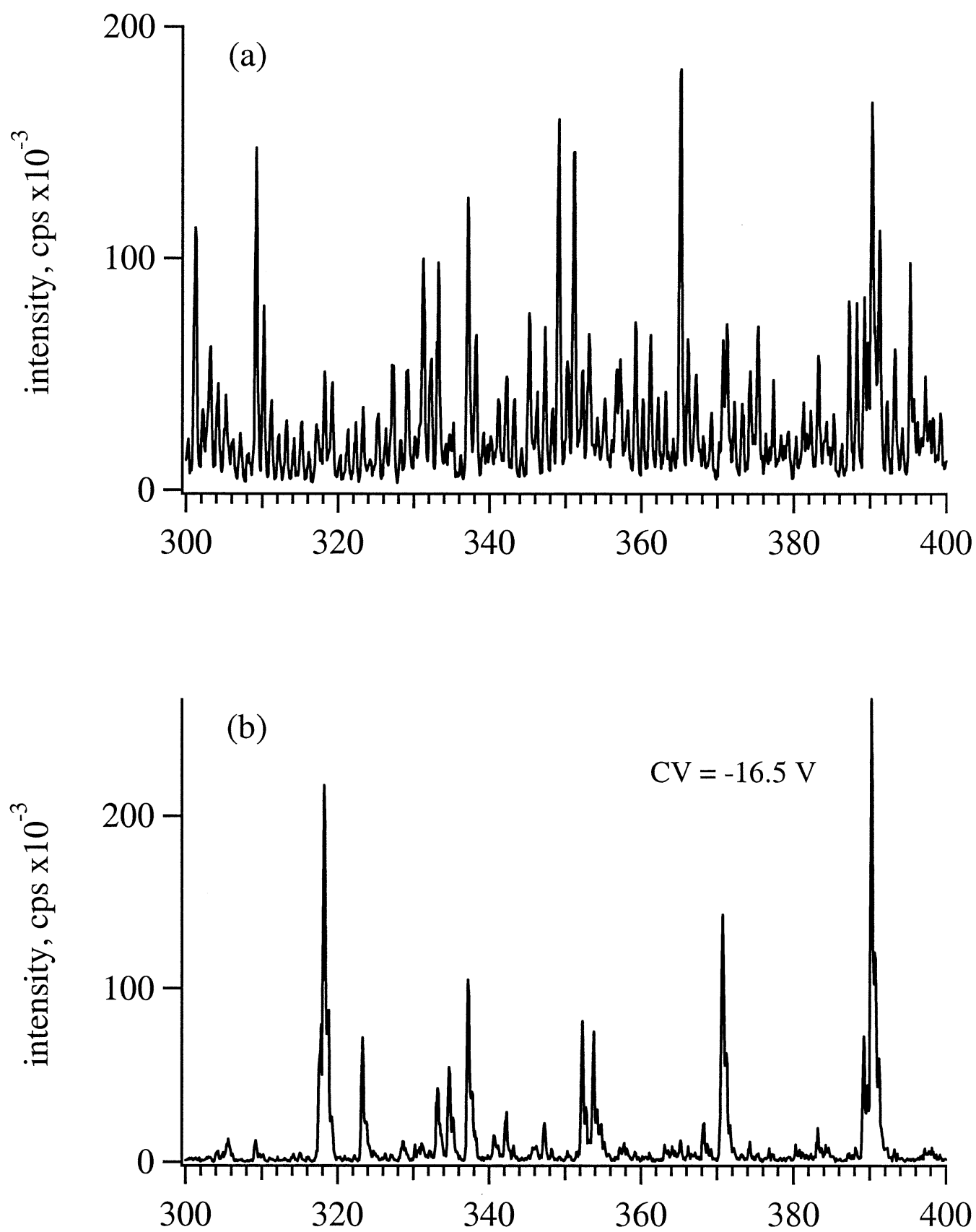

Figure 9. Expansion of Figure 8(a) and 8(b) from $m / z$ 300-400 showing a comparison of ESI and ESI-FAIMS mass spectra $(\mathrm{CV}=-16.5 \mathrm{~V})$ acquired for a mixture of six tryptic digests.

background reduction offered by the FAIMS technique are easily observed. For example, the intensity measured for IFVQK ( $\mathrm{m} / \mathrm{z}$ 317.8), a doubly-charged peptide of cytochrome $\mathrm{C}$ is 4.3 times higher in the FAIMS experiment, while the intensity of $\operatorname{HLDDLK}^{2+}(\mathrm{m} / \mathrm{z}$ $371)$, a tryptic peptide of sheep hemoglobin is 2.2 times higher using FAIMS.

\section{Conclusions}

An examination of the transmission of tryptic peptides through a FAIMS device suggest that coupling the FAIMS technology to condensed phase separation tech- niques (LC or CE) commonly employed in the analysis of biological samples warrants further investigation. The separation and focusing capabilities of the FAIMS device result in a reduction in the chemical background produced by the ESI process while increasing absolute ion intensities. Increased S/B ratios provided by FAIMS aid in the identification of low abundance tryptic peptides. Significant fractions of the multiply-charged tryptic peptides may be detected by monitoring ion signals with the FAIMS device set to transmit ions at a few CV values. A proposed LC-FAIMS-MS experiment would involve stepping the $\mathrm{CV}$ between two or three values chosen to transmit the majority of +2 and +3 peptides. 
While this approach will not identify all peptides in a mixture there is good indication that a combined LCFAIMS-MS method will identify low abundance peptides that may be lost in the noise of a traditional LC-MS analysis.

\section{Acknowledgments}

The authors thank Cherokee Hoaglund-Hyzer and David Clemmer of Indiana University for preparing the tryptic digest samples used in this study.

\section{References}

1. Kinter, M.; Sherman, N. E. Protein Sequencing and Identification Using Tandem Mass Spectrometry. John Wiley and Sons, Inc.: New York, 2000; pp 166-191.

2. Hoaglund, C. S.; Valentine, S. J.; Sporleder, C. R.; Reilly, J. P.; Clemmer, D. E. Three-Dimensional Ion Mobility/TOFMS Analysis of Electrosprayed Biomolecules. Anal. Chem. 1998, 70, 2236-2242.

3. Srebalus, C. A.; Li, J.; Marshall, W. S.; Clemmer, D. E. Gas-Phase Separations of Electrosprayed Peptide Libraries. Anal. Chem. 1999, 71, 3918-3927.

4. Srebalus Barnes, C. A.; Hilderbrand, A. E.; Valentine, S. J.; Clemmer, D. E. Resolving Isomeric Peptide Mixtures: A Combined HPLC/Ion Mobility-TOFMS Analysis of a 4000-Component Combinatorial Library. Anal. Chem. 2002, 74, 26-36.

5. Taraszka, J. A.; Counterman, A. E.; Clemmer, D. E. Gas-Phase Separations of Complex Tryptic Peptide Mixtures. Fresenius J. Anal. Chem. 2001, 369, 234-245.

6. Wu, C.; Siems, W. F.; Klasmeier, J.; Hill, Jr., H. H. Separation of Isomeric Peptides Using Electrospray Ionization/High Resolution Ion Mobility Spectrometry. Anal. Chem. 2000, 72, 391-395.

7. Wu, C.; Klasmeier, J.; Hill, Jr., H. H. Atmospheric Pressure Ion Mobility Spectrometry of Protonated and Sodiated Peptides. Rapid Commun. Mass Spectrom. 1999, 13, 1138-1142.

8. Wu, C.; Siems, W. F.; Asbury, G. R.; Hill, Jr., H. H. Electrospray Ionization High-Resoution Ion Mobility SpectrometryMass Spectrometry. Anal. Chem. 1998, 70, 4929-4938.

9. Wyttenbach, T.; Kemper, P. R.; Bowers, M. T. Design of a New Electrospray Ion Mobility Mass Spectrometer. Int. J. Mass Spectrom. 2001, 212, 13-23.

10. Purves, R. W.; Guevremont, R.; Day, S.; Pipich, C. W.; Matyjaszczyk, M. S. Mass Spectrometric Characterization of a High-Field Asymmetric Waveform Ion Mobility Spectrometer. Rev. Sci. Instrum. 1998, 69, 4094-4105.

11. Purves, R. W.; Guevremont, R. Electrospray Ionization-High Field Asymmetric Waveform Ion Mobility Spectrometry-Mass Spectrometry. Anal. Chem. 1999, 71, 2346-2357.

12. Guevremont, R.; Purves, R. W. High Field Asymmetric Waveform Ion Mobility Spectrometry-Mass Spectrometry: An Investigation of Leucine Enkephalin Ions Produced by Electrospray Ionization. J. Am. Soc. Mass Spectrom. 1999, 10, 492-501.
13. Guevremont, R.; Barnett, D. A.; Purves, R. W.; Vandermey, J. Analysis of a Tryptic Digest of Pig Hemoglobin Using ESIFAIMS-MS. Anal. Chem. 2000, 72, 4577-4584.

14. Barnett, D. A.; Ding, L.; Ells, B.; Purves, R. W.; Guevremont, R. Tandem Mass Spectra of Tryptic Peptides at Signal-to-Background Ratios Approaching Unity Using Electrospray Ionization High-Field Asymmetric Waveform Ion Mobility Spectrometry/Hybrid Quadrupole Time-of-Flight Mass Spectrometry. Rapid Commun. Mass Spectrom. 2002, 16, 676-680.

15. Hoaglund-Hyzer, C. S.; Lee, Y. J.; Counterman, A. E.; Clemmer, D. E. Coupling Ion Mobility Separations, Collisional Activation Techniques, and Multiple Stages of MS for Analysis of Complex Peptide Mixtures. Anal. Chem. 2002, 74, 992 1006.

16. Valentine, S. J.; Kulchania, M.; Barnes, C. A. S.; Clemmer, D. E. Multidimensional Separations of Complex Peptide Mixtures: A Combined High-Performance Liquid Chromatography/Ion Mobility/Time-of-Flight Mass Spectrometry Approach. Int. J. Mass Spectrom. 2001, 212, 97-109.

17. Guevremont, R.; Purves, R. W. Atmospheric Pressure Ion Focusing in a High-Field Asymmetric Waveform Ion Mobility Spectrometer. Rev. Sci. Instrum. 1999, 70(2), 1370-1383.

18. Buryakov, I. A.; Krylov, E. V.; Nazarov, E. G.; Rasulev, U. K. A New Method of Separation of Multi-Atomic Ions by Mobility at Atmospheric Pressure Using a High-Frequency Amplitude-Asymmetric Strong Electric Field. Int. J. Mass Spectrom. Ion Processes 1993, 128, 143-148.

19. Valentine, S. J.; Counterman, A. E.; Clemmer, D. E. A Database of 660 Peptide Ion Cross Section: Use of Intrinsic Size Parameters for Bona Fide Predictions of Cross Sections. J. Am. Soc. Mass Spectom. 1999, 10, 1188-1211.

20. Viehland, L. A.; Guevremont, R.; Purves, R. W.; Barnett, D. A. Comparison of High-Field Ion Mobility Obtained from Drift Tubes and a FAIMS Apparatus. Int. J. Mass Spectrom. 2000, 197, 123-130.

21. Barnett, D. A.; Ells, B.; Guevremont, R.; Purves, R. W.; Viehland, L. A. Evaluation of Carrier Gases for Use in High-Field Asymmetric Waveform Ion Mobility Spectrometry (FAIMS). J. Am. Soc. Mass Spectrom. 2000, 11, 1125-1133.

22. Barnett, D. A.; Purves, R. W.; Ells, B.; Guevremont, R. Separation of Ortho-, Meta-, and Paraphthalic Acids by HighField Asymmetric Wavefrom Ion Mobility Spectrometry Using Mixed Carrier Gases. J. Mass Spectrom. 2000, 35(8), 976-980.

23. Ells, B.; Barnett, D. A.; Purves, R. W.; Guevremont, R. Detection of Nine Chlorinated and Brominated Haloacetic Acids at Part-per-Trillion Levels Using ESI-FAIMS-MS. Anal. Chem. 2000, 72(19), 4555-4559.

24. Purves, R. W.; Barnett, D. A.; Ells, B.; Guevremont, R. Elongated Conformers of Charge States +11 to +15 of Bovine Ubiquitin Studied Using ESI-FAIMS-MS. J. Am. Soc. Mass Spectrom. 2001, 12, 894-901.

25. McCooeye, M. A.; Ells, B.; Barnett, D. A.; Purves, R. W.; Guevremont, R. Quantitation of Morphine and Codeine in Human Urine Using High-Field Asymmetric Waveform Ion Mobility Spectrometry (FAIMS) with Mass Spectrometric Detection. J. Anal. Toxicol. 2001, 25, 81-87. 